\title{
Measuring Out-of-pocket Payment, Catastrophic Health Expenditure and the Related Socioeconomic Inequality in Peru: A Comparison Between 2008 and 2017
}

\author{
Akram Hernández-Vásquez ${ }^{1}$, Carlos Rojas-Roque ${ }^{2}$, Rodrigo Vargas-Fernández ${ }^{3}$, Diego Rosselli ${ }^{4}$ \\ 'Universidad San Ignacio de Loyola, Vicerrectorado de Investigación, Centro de Excelencia en Investigaciones Económicas y Sociales en Salud, Lima, \\ Peru; ${ }^{2}$ Centro de Investigación en Demografía y Salud, Leon, Nicaragua; ${ }^{3}$ Facultad de Medicina Humana, Universidad Científica del Sur, Lima, Peru; \\ ${ }^{4}$ Clinical Epidemiology and Biostatistics Department, Pontificia Universidad Javeriana, Medical School, Bogota, Colombia
}

Objectives: Describe out-of-pocket payment (OOP) and the proportion of Peruvian households with catastrophic health expenditure (CHE) and evaluate changes in socioeconomic inequalities in CHE between 2008 and 2017.

Methods: We used data from the 2008 and 2017 National Household Surveys on Living and Poverty Conditions (ENAHO in Spanish), which are based on probabilistic stratified, multistage and independent sampling of areas. OOP was converted into constant dollars of 2017. A household with CHE was assumed when the proportion between OOP and payment capacity was $\geq 0.40$. OOP was described by median and interquartile range while CHE was described by weighted proportions and $95 \%$ confidence intervals (Cls). To estimate the socioeconomic inequality in CHE we computed the Erreygers concentration index.

Results: The median OOP reduced from 205.8 US dollars to 158.7 US dollars between 2008 and 2017. The proportion of CHE decreased from $4.9 \%(95 \% \mathrm{Cl}, 4.5$ to 5.2$)$ in 2008 to $3.7 \%(95 \% \mathrm{Cl}, 3.4$ to 4.0$)$ in 2017. Comparison of socioeconomic inequality of CHE showed no differences between 2008 and 2017, except for rural households in which CHE was less concentrated in richer households $(p<0.05)$ and in households located on the rest of the coast, showing an increase in the concentration of CHE in richer households $(p<0.05)$. Conclusions: Although OOP and CHE reduced between 2008 and 2017, there is still socioeconomic inequality in the burden of CHE across different subpopulations. To reverse this situation, access to health resources and health services should be promoted and guaranteed to all populations.

Key words: Health expenditure, Healthcare disparities, Financial risk sharing, Universal health insurance, Peru

\section{INTRODUCTION}

Received: February 10, 2020 Accepted: May 20, 2020

Corresponding author: Akram Hernández-Vásquez, MD Universidad San Ignacio de Loyola, Vicerrectorado de Investigación, Centro de Excelencia en Investigaciones Económicas y Sociales en Salud, La Fontana 550, La Molina, Lima, Peru

E-mail: ahernandez@usil.edu.pe

This is an Open Access article distributed under the terms of the Creative Commons Attribution Non-Commercial License (https://creativecommons.org/licenses/by$\mathrm{nc} / 4.0 /$ ) which permits unrestricted non-commercial use, distribution, and reproduction in any medium, provided the original work is properly cited.
The 2005 World Health Assembly stated that everyone has the right to access healthcare and not to suffer financial difficulties by doing so; this right has been included in the Sustainable Development Goals [1]. Governments are concerned about how to finance Universal Health Coverage (UHC) [2], and in low-income and middle-income countries this concern is greater given the difficulties of health systems to meet the diverse needs of the population.

Non-reimbursable payment made by people who use a 
health service, known as out-of-pocket payment (OOP), is one of the means of financing a health system. OOP is more frequent in countries that depend on user fees to contain the costs of the system and rationalize the use of health services [3]. However, OOP may be inefficient and can generate inequalities in health access and financing because of the lower capacity of low-income households to pay for health services [4]. These households may incur catastrophic health expenditure (CHE) when high OOP levels exceed a certain proportion of their payment capacity [5].

Globally more than 800 million people incurred in CHE in 2010 [6], and in some countries up to $11.0 \%$ of the population suffers from CHE annually [7], thereby accentuating their level of poverty, maintaining the burden of disease and jeopardizing the achievement of UHC by healthcare systems. Policies such as free public health insurance or financing access to health through taxes are some strategies to achieve UHC and reduce CHE [8].

The total health expenditure in Peru is lower than the average in Latin America (5.5\% vs. $7.1 \%$ of the gross domestic product, respectively). The per capita expenditure in health in 2014 was 656 dollars power parity purchase (PPP), being less than the average spent in other Latin American countries (PPP 1479) $[9,10]$. OOP represents $31 \%$ of total expenditure in health, similar to the Latin America average $[9,10]$.

In Peru, OOP has reduced since 2008 due to substantial increases in prepaid public financing $[9,10]$. The percentage of people enrolled in any form of health insurance increased from $53.7 \%$ in 2008 to $76.4 \%$ in 2017 [11]. However, many do not attend outpatient consultations due to insufficient resources to meet aging population and epidemiological transition health needs [12] as well as the dissatisfaction they perceive with the health system [13]. In addition, the fragmented and decentralized health system in Peru may induce inefficiencies, ineffectiveness and commoditization of healthcare [14]. Thus, the health system may not adequately respond to the health needs of socially disadvantaged people, increasing the risk of impoverishment due to OOP. There is evidence of an increase in OPP for medications in previous years [15], and a recent study found that in $2016,4.0 \%$ of Peruvian households had CHE; households with older adults or people with chronic disease [16].

It is important to evaluate OOP and CHE as indicators of health system performance in order to design and implement more comprehensive and equitable health policies. The aim of this study was to describe both OOP and the proportion of Peruvi- an households with $\mathrm{CHE}$, as well as to evaluate changes in socioeconomic inequalities in CHE between 2008 and 2017.

\section{METHODS}

\section{Study Design and Data Sources}

We analysed secondary data from the National Household Survey on Living Conditions and Poverty (ENAHO in Spanish) compiled by the National Institute of Statistics and Informatics of Peru (INEl in Spanish), for the years 2008 and 2017 (the last survey available at the time of the study). These years were chosen in order to describe the levels of OOP and the proportion of households with CHE one year before and eight years after the implementation of the UHC policy in 2009, but avoided establishing relationships or assessing the real impact of the UHC policy.

ENAHO is an annual survey that collects information on the living conditions of the Peruvian population. The study population includes the set of all urban and rural households. The survey is based on probabilistic stratified, multistage and independent sampling of areas that is representative at the national, departmental, geographic and urban/rural levels. The databases were obtained anonymously and freely available at the website of the INEI (http://iinei.inei.gob.pe/microdatos/).

The size of the national sample of households included in ENAHO for the years 2008 and 2017 was 22640 and 36 996, respectively. After excluding households with missing data, 21461 (94.8\%) and 34576 (93.5\%) households were included in the analysis, respectively.

\section{Measuring Out-of-pocket and Catastrophic Spending}

Among the continuous variables, OOP was the main study variable. To adjust comparisons of OPP among households with different socioeconomic status, CHE (yes/no) was chosen as a second main variable.

In the ENAHO survey, the variable OOP is the sum of all the payments disbursed by a member of the household for the following health services: medical consultation, medicines, medical examinations and laboratory tests ( $\mathrm{X}$-rays, tomography, haemodialysis, among others), dental and related services, ophthalmological services (ophthalmology consultations and the purchase of lenses), child healthcare (vaccines, health control), hospitalization, surgical intervention, maternal health (control of pregnancy and delivery care) and other health ser- 
vices (contraceptives, rehabilitation, among others). In 2008, the ENAHO did not include payments disbursed for surgical intervention because they are included in hospitalization services.

The reference period for the reported payments were the previous 4 weeks for medical consultation, medicines, medical tests and laboratory tests; the previous 3 months for dental and related services, ophthalmological services, child healthcare and other health services; and the previous 12 months for hospitalization, surgical intervention and maternal health.

The monetary values of OOP were converted to constant prices using the consumer price index, taking 2017 as the reference year [17]. The 2017 base year soles were then converted to US dollars (USD) using the average annual exchange rate for 2017 (1 USD = 3.246 soles) [18].

Although there is still no consensus on the definition of CHE, it is widely accepted that CHE should be measured in relation to the household monetary spending capacity [19]. The monetary expenditure capacity of the household is defined as nonsubsistence expenditure, which is calculated as the total household expenditure less the expenditure on basic needs.

In this study, we calculated monetary expenditure capacity by subtracting the total annual monetary expenditure from the total annual food expenditure. To estimate CHE in households, the proportion between OOP (numerator) and the monetary expenditure capacity (denominator) of the household was calculated [20-22]. CHE was considered when the proportion was $\geq 0.40$. This threshold coincides with other studies that use this methodology [20-22] and estimate CHE in this way $[16,19,23]$. In addition, to better understand as well as better compare our results, we performed CHE with thresholds of $0.1,0.2$, and 0.3 .

\section{Independent Variables}

The independent variables considered were the following: sex of household head, age grouped in years of household head, household size, elderly members in the household, children in the household, household members with chronic conditions, residence area, natural region, any member of the household with health insurance, and poverty level in the household.

\section{Statistical Analysis}

Database integration, processing and statistical analysis were performed using Stata version 14.2 (StataCorp., College Station, TX, USA). All the analyses were carried out considering the characteristics of the sample design of the survey that in- cluded the factors of expansion (factor07) of ENAHO.

Socio-demographic characteristics of the households were described by frequency and weighted proportions analysis. OOP was expressed as median and interquartile range. To describe $\mathrm{CHE}$, the weighted proportion and the $95 \%$ confidence interval $(\mathrm{Cl})$ were estimated.

To estimate socioeconomic inequality in $\mathrm{CHE}$, we estimated Erreygers concentration indices (ECl) according to the household annual per capita adjusted expenditure as a proxy variable for ordering households according to their level of wealth. This decision was taken because the results of the Pearson correlation coefficient showed a strong relationship between household income and household expenditure $(r=0.77)$. Furthermore, since household expenditures are more stable in comparison to household income, the structure of expenditure and consumer spending may reflect the economic wellbeing of the households [24]. Lastly, INEI and other national institutions jointly estimated the poverty levels using household expenditures [25].

The annual per capita adjusted expenditure was constructed dividing the total annual expenditure of the household by the total number of household members. Then we applied equivalence scales in order to adjust the expenditures of the households due to the size of the household and the age of its members (considering whether they are adults or children). The methodology used has been described elsewhere [26-28].

We calculated the $\mathrm{ECl}$ due to the binary characteristics of CHE. ECI has methodological advantages in comparison to the standard concentration index when the outcome variable is dichotomous [29]. Mathematically,

$$
\operatorname{ECI}(a \mid y)=\frac{1}{n} \sum_{i=1}^{n}\left[\frac{4 a_{i}}{\left(a^{\text {max }}-a^{\text {min }}\right)}\left(2 R_{i}-1\right)\right]
$$

in which $a_{i} \in\left[a^{\min }, a^{\max }\right]$ denotes the variable CHE with the limit values 0 and 1 and $R_{i}-1$ denotes the fractional range of per capita expenditure. The values for any $E C I$ range from -1 to 1 , reflecting the variability and strength of the relationship among the variables studied. The values are positive (negative) when there is a greater CHE for households with higher (lower) levels of per capita expenditure.

\section{Ethics Statement}

This study did not require institutional review board ethical approval because it analyses public domain secondary aggre- 
gated data that cannot be used to identify the participants surveyed.

\section{RESULTS}

The socio-demographic characteristics of the individuals and households included in the study are described in Table 1. In both years, most of the household heads were male, between 35 years and 54 years of age. In 2008, $74.0 \%$ of households had a member with health insurance, while in 2017 this percentage was $88.5 \%$. Non-poor households accounted for $68.8 \%$ in 2008 and $82.6 \%$ in 2017 (Table 1).

The median OOP decreased from 205.8 USD to 158.7 USD between 2008 and 2017. Non-extremely poor households $(-47.3 \%)$, extremely poor households (-39.2\%) and rural households $(-34.1 \%)$ showed the greatest reduction in OOP. For both years, the households with the highest median OOP were those located in Metropolitan Lima, non-poor households, households with at least 1 member with chronic disease, and households in the urban area (Table 2).

Households with CHE decreased from $4.9 \%(95 \% \mathrm{Cl}, 4.5$ to $5.2)$ in 2008 to $3.7 \%(95 \% \mathrm{Cl}, 3.4$ to 4.0$)$ in 2017 . Households with six or more members $(-61.9 \%)$ and households with children under five years of age (-53.7\%) largely reduced CHE during the time span. In 2008, CHE was more frequent in households with elderly members, rural households and households with members with chronic conditions. In 2017, CHE was more frequent in households with elderly members, households with 1 to 3 members, households in rural areas and households without members with health insurance. Gaps in CHE between poor and non-poor households increased from 1.6 to 1.9 percentage points between 2008 and 2017. On the other hand, the gaps decreased from 3.4 in 2008 to 1.8 percentage points in 2017 among urban and rural households (Table 2).

At cut-off points of $0.1,0.2$, and 0.3 , CHE was $36.0 \%, 17.8 \%$, and $9.1 \%$, respectively, in 2008 , and $28.1 \%, 13.2 \%$, and $6.8 \%$, respectively, in 2017 (Supplemental Material 1).

Table 3 shows the concentration index for CHE. For rural households, CHE was less concentrated in richer households in 2017 in comparison to $2008(p<0.05)$; and in households located on the rest of the coast in 2017, the concentration of CHE increased in richer households compared to 2008 $(p<0.01)$. For the rest of the subgroups, the comparison of the inequality of CHE did not show any difference between 2008 and 2017. There were no differences in inequality of CHE be-
Table 1. Socio-demographic characteristics of the Peruvian households, 2008 and 2017 National Household Surveys on Living and Poverty Conditions (ENAHO in Spanish) surveys

\begin{tabular}{|c|c|c|}
\hline Characteristics & $2008(n=21461)^{1}$ & $2017(n=34576)^{1}$ \\
\hline \multicolumn{3}{|l|}{ Sex of household head } \\
\hline Male & $16696(76.4)$ & $25042(70.5)$ \\
\hline Female & $4765(23.6)$ & $9534(29.5)$ \\
\hline \multicolumn{3}{|c|}{ Age grouped in years of household head (y) } \\
\hline $15-24$ & $655(3.0)$ & $622(1.8)$ \\
\hline $25-34$ & $3417(15.2)$ & $3919(11.1)$ \\
\hline $35-44$ & $5085(23.2)$ & $6949(20.2)$ \\
\hline $45-54$ & $4866(22.7)$ & $7997(23.4)$ \\
\hline $55-64$ & $3546(17.1)$ & $6831(20.2)$ \\
\hline$\geq 65$ & $3895(18.8)$ & $8258(23.3)$ \\
\hline \multicolumn{3}{|l|}{ Household size (n) } \\
\hline $1-3$ & $8719(40.6)$ & $17668(49.7)$ \\
\hline $4-5$ & $7784(37.5)$ & $11916(35.7)$ \\
\hline$\geq 6$ & $4958(21.9)$ & $4992(14.6)$ \\
\hline \multicolumn{3}{|c|}{ Elderly members ( $\geq 65 y$ ) in the household } \\
\hline No & $16431(75.7)$ & $24518(71.2)$ \\
\hline Yes & $5030(24.3)$ & $10058(28.8)$ \\
\hline \multicolumn{3}{|c|}{ Young children $(<5 y)$ in the household } \\
\hline No & $14650(69.7)$ & $26377(76.6)$ \\
\hline Yes & $6811(30.3)$ & $8199(23.4)$ \\
\hline \multicolumn{3}{|c|}{ Household members with chronic conditions } \\
\hline No & $8598(38.6)$ & $8634(24.1)$ \\
\hline Yes & $12863(61.4)$ & $25942(75.9)$ \\
\hline \multicolumn{3}{|l|}{ Residence area } \\
\hline Urban & $13065(73.7)$ & $21667(76.6)$ \\
\hline Rural & $8396(26.3)$ & $12909(23.4)$ \\
\hline \multicolumn{3}{|l|}{ Natural region } \\
\hline Metropolitan Lima & $2688(30.9)$ & $4058(30.9)$ \\
\hline Rest of the coast & $5518(23.4)$ & $10309(22.9)$ \\
\hline Andean & $8764(33.9)$ & $13190(34.2)$ \\
\hline Amazon & 4491 (11.8) & $7019(12.0)$ \\
\hline \multicolumn{3}{|c|}{ Any member of the household with health insurance } \\
\hline No & $5548(26.0)$ & $3809(11.5)$ \\
\hline Yes & $15913(74.0)$ & 30767 (88.5) \\
\hline \multicolumn{3}{|c|}{ Poverty level in the household } \\
\hline Non-poor & $13770(68.8)$ & $28119(82.6)$ \\
\hline Poor & 7691 (31.2) & 6457 (17.4) \\
\hline Extreme poor & $2574(28.1)$ & $1211(16.5)$ \\
\hline Non-extreme poor & 5117 (71.8) & 5246 (83.5) \\
\hline
\end{tabular}

Values are presented as number (\%).

${ }^{1}$ Count "number" are unweighted. The proportions include the expansion factor and the complex survey design of ENAHO in both years.

tween 2008 and 2017.

Most of the households classified as poor with CHE reduced 
Table 2. Trends in the level of OOP and the proportion of CHE in Peruvian households, 2008 and 2017 National Household Surveys on Living and Poverty Conditions (ENAHO in Spanish) survey

\begin{tabular}{|c|c|c|c|c|c|c|}
\hline \multirow[b]{2}{*}{$\begin{array}{l}\text { Household } \\
\text { characteristics }\end{array}$} & \multicolumn{3}{|c|}{ Annual 00P level (USD)² } & \multicolumn{3}{|c|}{ Proportion of household with $\mathrm{CHE}$ at 0.4 threshold } \\
\hline & $\begin{array}{c}2008 \\
\text { Median (01-03) }\end{array}$ & $\begin{array}{c}2017 \\
\text { Median (01-03) }\end{array}$ & $\begin{array}{l}\text { Percent change in the } \\
\text { level of 00P from } \\
2008 \text { to } 2017(\%)\end{array}$ & $\begin{array}{c}2008 \\
\%(95 \% \mathrm{CI})\end{array}$ & $\begin{array}{c}2017 \\
\%(95 \% \text { CI })\end{array}$ & $\begin{array}{l}\text { Percent change in } \\
\text { CHE from } \\
2008 \text { to } 2017(\%)\end{array}$ \\
\hline Total population & $205.8(57.6-592.8)$ & $158.7(39.4-488.6)$ & -22.9 & $4.9(4.5,5.2)$ & $3.7(3.4,4.0)$ & -24.5 \\
\hline \multicolumn{7}{|c|}{ Sex of the household head } \\
\hline Male & $207.5(58.1-605.4)$ & $157.1(39.7-497.8)$ & -24.3 & $4.8(4.4,5.2)$ & $3.5(3.2,3.8)$ & -27.1 \\
\hline \multicolumn{7}{|c|}{ Age in grouped years of household head (y) } \\
\hline $15-24$ & $86.08(32.07-246.87)$ & $105.36(31.42-288.04)$ & 22.4 & $1.7(0.8,3.3)$ & $0.5(0.2,1.3)$ & -70.6 \\
\hline $25-34$ & $144.14(46.28-389.79)$ & $114.60(35.12-352.12)$ & -25.9 & $3.2(2.5,4.0)$ & $1.7(1.2,2.3)$ & -88.2 \\
\hline $35-44$ & $179.46(50.75-486.43)$ & $132.77(37.27-388.47)$ & -26.0 & $3.3(2.7,4.0)$ & $1.6(1.2,2.0)$ & -51.5 \\
\hline $45-54$ & $240.37(69.83-647.63)$ & $179.60(48.05-532.96)$ & -25.3 & $4.0(3.3,4.7)$ & $2.3(1.9,2.7)$ & -42.5 \\
\hline $1-3$ & $157.9(44.2-476.7)$ & $118.0(29.6-387.2)$ & -25.3 & $5.9(5.3,6.5)$ & $5.5(5.1,6.0)$ & -6.8 \\
\hline $4-5$ & $231.4(69.8-646.4)$ & $182.4(55.1-540.4)$ & -21.2 & $4.2(3.6,4.7)$ & $2.1(1.7,2.4)$ & -50.0 \\
\hline$\geq 6$ & $254.6(72.3-686.6)$ & $223.7(63.8-638.4)$ & -12.1 & $4.2(3.5,4.9)$ & $1.6(1.2,2.0)$ & -61.9 \\
\hline \multicolumn{7}{|c|}{ Elderly members ( $\geq 65 \mathrm{y}$ ) in the household } \\
\hline No & $192.5(54.4-530.3)$ & $149.1(38.8-458.1)$ & -22.5 & $3.7(3.3,4.1)$ & $2.3(2.1,2.6)$ & -37.8 \\
\hline Yes & $275.3(70.6-840.5)$ & $184.8(41.9-583.5)$ & -32.9 & $8.6(7.6,9.6)$ & $7.3(6.6,8.0)$ & -15.1 \\
\hline \multicolumn{7}{|c|}{ Young children $(<5 y)$ in the household } \\
\hline No & $208.7(56.8-609.8)$ & $152.8(37.3-479.4)$ & -26.8 & $5.2(4.8,5.7)$ & $4.3(4.0,4.6)$ & -17.3 \\
\hline Yes & $201.0(59.3-559.5)$ & $172.2(48.1-513.6)$ & -14.3 & $4.1(3.5,4.7)$ & $1.9(1.5,2.3)$ & -53.7 \\
\hline \multicolumn{7}{|l|}{ Natural region } \\
\hline Metropolitan Lima & $361.8(122.2-891.3)$ & $293.8(87.5-760.6)$ & -18.8 & $4.0(3.2,4.8)$ & $3.0(2.4,3.6)$ & -25.0 \\
\hline Rest of the coast & $207.1(66.2-558.7)$ & $177.4(55.5-497.2)$ & -14.3 & $5.0(4.3,5.7)$ & $3.9(3.4,4.4)$ & -22.0 \\
\hline Andean & $108.8(29.2-361.8)$ & $77.6(18.8-273.9)$ & -28.7 & $5.2(4.7,5.8)$ & $4.5(4.1,4.9)$ & -13.5 \\
\hline Amazon & $145.4(48.7-404.4)$ & $103.8(30.8-301.0)$ & -28.6 & $5.8(5.0,6.7)$ & $2.9(2.5,3.4)$ & -50.0 \\
\hline \multicolumn{7}{|c|}{ Any member of the household with health insurance } \\
\hline No & $162.4(48.7-458.4)$ & $138.3(37.0-408.8)$ & -14.8 & $5.6(4.8,6.3)$ & $5.1(4.1,6.1)$ & -8.9 \\
\hline Yes & $223.3(63.3-641.5)$ & $161.7(40.4-500.9)$ & -27.6 & $4.6(4.2,5.1)$ & $3.6(3.3,3.8)$ & -21.7 \\
\hline \multicolumn{7}{|c|}{ Poverty level in the household } \\
\hline Non-poor & $294.4(89.3-772.3)$ & $195.9(55.1-562.5)$ & -33.5 & $5.4(4.9,5.8)$ & $4.1(3.7,4.4)$ & -24.1 \\
\hline Poor & $75.1(24.4-212.0)$ & $42.5(12.9-130.3)$ & -43.4 & $3.8(3.3,4.3)$ & $2.2(1.8,2.7)$ & -42.1 \\
\hline Extreme poor & $36.5(13.0-95.4)$ & $22.2(7.4-59.1)$ & -39.2 & $4.0(3.1,4.9)$ & $2.8(1.6,4.0)$ & -30.0 \\
\hline Non-extreme poor & $94.6(30.8-247.7)$ & $49.9(14.8-145.7)$ & -47.3 & $3.8(3.2,4.4)$ & $2.1(1.6,2.6)$ & -44.7 \\
\hline
\end{tabular}

OOP, out-of-pocket payment; CHE, catastrophic health expenditure; USD, US dollar; 01-03, percentile 25 - percentile 75.

${ }^{1}$ Estimations include the factor expansion and the complex survey design of ENAHO for both years.

2Exchange rate: 1 US dollar $=3.246$ soles. 
Table 3. Inequality in the burden of catastrophic health expenditure (CHE) across Peruvian households, 2008 and 2017 National Household Surveys on Living and Poverty Conditions (ENAHO in Spanish) survey

\begin{tabular}{|c|c|c|c|}
\hline \multirow{2}{*}{$\begin{array}{l}\text { Households } \\
\text { characteristics }\end{array}$} & \multicolumn{2}{|c|}{ Concentration index for CHE } & \multirow{2}{*}{$p$-value } \\
\hline & 2008 & 2017 & \\
\hline Total population & 0.001 & $0.006^{\dagger}$ & 0.371 \\
\hline \multicolumn{4}{|c|}{ Sex of household head } \\
\hline Male & 0.000 & 0.003 & 0.659 \\
\hline Female & 0.006 & $0.013^{\dagger}$ & 0.561 \\
\hline \multicolumn{4}{|c|}{ Age in grouped years of household head (y) } \\
\hline $15-24$ & $-0.022^{\dagger}$ & 0.002 & 0.080 \\
\hline $25-34$ & 0.005 & -0.001 & 0.603 \\
\hline $35-44$ & -0.003 & 0.005 & 0.371 \\
\hline $45-54$ & -0.003 & -0.001 & 0.830 \\
\hline $55-64$ & -0.002 & 0.001 & 0.826 \\
\hline$\geq 65$ & 0.016 & $0.027^{* * *}$ & 0.504 \\
\hline \multicolumn{4}{|l|}{ Household size (n) } \\
\hline $1-3$ & -0.001 & 0.003 & 0.639 \\
\hline $4-5$ & 0.003 & $0.007^{\dagger}$ & 0.590 \\
\hline$\geq 6$ & -0.007 & 0.000 & 0.447 \\
\hline \multicolumn{4}{|c|}{ Elderly members ( $\geq 65 \mathrm{y}$ ) in the household } \\
\hline No & -0.004 & 0.004 & 0.116 \\
\hline Yes & $0.025^{*}$ & $0.019 *$ & 0.688 \\
\hline \multicolumn{4}{|c|}{ Young children $(<5 y)$ in the household } \\
\hline No & 0.000 & 0.002 & 0.759 \\
\hline Yes & -0.004 & $0.008^{\dagger}$ & 0.150 \\
\hline \multicolumn{4}{|c|}{ Household members with chronic conditions } \\
\hline No & $-0.008^{\dagger}$ & $-0.006^{\dagger}$ & 0.723 \\
\hline Yes & -0.003 & $0.014^{*}$ & 0.065 \\
\hline \multicolumn{4}{|l|}{ Settlement } \\
\hline Urban & $0.015^{* * *}$ & $0.013^{* * *}$ & 0.832 \\
\hline Rural & $0.065^{* * *}$ & $0.041^{* * *}$ & 0.017 \\
\hline \multicolumn{4}{|l|}{ Natural region } \\
\hline Metropolitan Lima & $0.022^{* * *}$ & $0.012^{\dagger}$ & 0.338 \\
\hline Rest of the coast & -0.001 & $0.027^{* * *}$ & 0.013 \\
\hline Highlands & 0.009 & $0.009^{\dagger}$ & 0.957 \\
\hline Jungle & 0.009 & $0.139 *$ & 0.701 \\
\hline \multicolumn{4}{|c|}{ Any member of the household with health insurance } \\
\hline No & -0.001 & $0.024^{\dagger}$ & 0.123 \\
\hline Yes & 0.002 & 0.004 & 0.799 \\
\hline
\end{tabular}

${ }^{\dagger} p<0.1,{ }^{*} p<0.05,{ }^{* * *} p<0.001$.

0.5 percentage points or more between 2008 and 2017 (Table 4). In 2008, in La Libertad, San Martin and Pasco, households classified as poor had a higher CHE compared to other households classified as poor in other departments. In 2017, households classified as poor in Tumbes, Puno and Cajamarca had a
Table 4. Proportion of household with catastrophic health expenditure according to poverty condition, 2008 and 2017 National Household Surveys on Living and Poverty Conditions (ENAHO in Spanish) survey

\begin{tabular}{|c|c|c|c|c|}
\hline \multirow{2}{*}{$\begin{array}{l}\text { Depart- } \\
\text { ments }\end{array}$} & \multicolumn{2}{|c|}{2008} & \multicolumn{2}{|c|}{2017} \\
\hline & Non-poor & Poor & Non-poor & Poor \\
\hline Amazonas & $13.1(9.7,16.4)$ & $5.5(3.1,7.8)$ & $6.5(4.7,8.3)$ & $3.0(1.2,4.8)$ \\
\hline Ancash & $6.9(4.9,8.8)$ & $3.5(1.5,5.6)$ & $5.8(4.3,7.3)$ & $3.2(1.1,5.3)$ \\
\hline Apurímac & $7.8(4.2,11.4)$ & $2.6(1.1,4.0)$ & $3.8(2.2,5.3)$ & $2.2(0.5,3.8)$ \\
\hline Arequipa & $4.4(2.9,5.9)$ & $2.6(0.0,6.1)$ & $1.9(1.2,2.6)$ & $1.5(0.0,3.7)$ \\
\hline Ayacucho & $7.4(4.7,10.2)$ & $3.8(2.1,5.6)$ & $6.7(4.9,8.4)$ & $2.4(0.7,4.1)$ \\
\hline Cajamarca & $11.6(8.5,14.7)$ & $6.5(4.3,8.6)$ & $6.2(4.6,7.7)$ & $3.3(2.0,4.7)$ \\
\hline Callao & $4.9(2.8,6.9)$ & $1.9(0.0,4.1)$ & $3.6(2.4,4.9)$ & $2.2(0.0,5.3)$ \\
\hline Cusco & $5.7(3.4,8.0)$ & $1.6(0.0,3.0)$ & $4.4(2.8,6.0)$ & $0.9(0.0,2.0)$ \\
\hline Huancavelica & $6.9(3.1,10.7)$ & $1.4(0.3,2.4)$ & $4.0(2.4,5.7)$ & $1.3(0.0,2.8)$ \\
\hline Huanuco & $2.9(1.1,4.7)$ & $2.4(1.1,3.7)$ & $3.9(2.7,5.2)$ & $2.9(1.1,4.7)$ \\
\hline Ica & $2.5(1.4,3.6)$ & $1.1(0.0,2.6)$ & $1.2(0.0,1.9)$ & $0.0(0.0,0.0)$ \\
\hline Junín & $4.0(2.6,5.3)$ & $3.1(1.0,5.1)$ & $5.0(3.4,6.6)$ & $1.6(0.3,2.9)$ \\
\hline La Libertad & $6.0(3.9,8.1)$ & $10.2(6.3,14.1)$ & $5.8(4.4,7.3)$ & $2.9(1.0,4.8)$ \\
\hline Lambayeque & $6.4(4.2,8.5)$ & $5.7(1.7,9.8)$ & $4.0(2.8,5.1)$ & $1.9(0.0,4.1)$ \\
\hline Lima & $5.0(4.0,5.9)$ & $1.5(0.0,2.5)$ & $3.5(2.8,4.1)$ & $1.2(0.0,2.4)$ \\
\hline Loreto & $2.0(0.6,3.3)$ & $3.2(1.4,5.0)$ & $1.5(0.7,2.2)$ & $1.3(0.0,2.6)$ \\
\hline $\begin{array}{l}\text { Madre de } \\
\text { Dios }\end{array}$ & $1.4(0.5,2.3)$ & $2.2(0.0,6.6)$ & $1.2(0.3,2.0)$ & $0.0(0.0,0.0)$ \\
\hline Moquegua & $2.3(0.9,3.7)$ & $1.2(0.0,2.9)$ & $2.9(1.7,4.0)$ & $0.0(0.0,0.0)$ \\
\hline Pasco & $6.0(3.1,8.9)$ & $6.3(3.6,9.0)$ & $4.1(2.6,5.7)$ & $1.8(0.2,3.4)$ \\
\hline Piura & $5.7(3.8,7.7)$ & $5.1(2.5,7.8)$ & $5.3(3.9,6.7)$ & $1.7(0.4,3.1)$ \\
\hline Puno & $5.2(2.7,7.7)$ & $3.7(1.9,5.4)$ & $5.3(3.5,7.1)$ & $4.0(0.9,7.0)$ \\
\hline San Martín & $10.0(6.9,13.2)$ & $7.6(4.4,10.7)$ & $5.5(3.9,7.0)$ & $1.4(0.0,2.7)$ \\
\hline Tacna & $3.5(1.8,5.2)$ & $2.3(0.0,5.5)$ & $4.2(2.8,5.7)$ & $2.8(0.0,6.3)$ \\
\hline Tumbes & $3.0(1.6,4.4)$ & $1.8(0.0,4.2)$ & $3.7(2.2,5.3)$ & $4.5(0.0,9.8)$ \\
\hline Ucayali & $2.7(1.3,4.1)$ & $3.8(1.2,6.4)$ & $0.6(0.0,1.2)$ & $1.9(0.2,3.6)$ \\
\hline
\end{tabular}

Values are presented as \% (95\% confidence interval).

higher CHE compared to other households classified as poor in other departments.

\section{DISCUSSION}

This study provides evidence that both OOP and CHE in Peru decreased between 2008 and 2017. CHE seemed to be concentrated in richer households and the comparison of inequality showed no differences between 2008 and 2017, except for rural households in which CHE became less concentrated in richer households and in households located on the rest of the coast, in which CHE became more concentrated in richer households.

The reduction of OOP, especially in households with social 
disadvantage in Peru, goes against the evidence of a growing trend of OOP in Latin America [24] and other countries such as Chile [4]. This reduction may be explained because a larger proportion of poor people, or people without health insurance, increased their access to health through the Comprehensive Health Insurance $(\mathrm{CHI})$, which rose from $17.0 \%$ of affiliates in 2007 to $46.3 \%$ in 2016 [30]. However, further analysis is required to assess the real impact of $\mathrm{CHI}$ in OOP. A second possible explanation is that, even though medications are free of charge, the poorest individuals simply forgo their health needs and health expenses because they cannot afford other expenses such as transportation costs or indirect costs such as income loss due to medical appointments. One study found that $12.9 \%$ of Peruvians reported that they did not receive medical care because they did not have money, and $43.1 \%$ of people in moderate or extreme poverty claimed that money was a barrier for access to healthcare [31].

The reduction of $\mathrm{CHE}$ in Peru was similar to national estimates of a retrospective study worldwide [6], although it differs from the growing trend of $\mathrm{CHE}$ in countries in other parts of the world, such as Cambodia [32], Iran [33], India [34], or countries in the region, such as Brazil [35] and Chile [4]. Differences in population characteristics, poverty rates, national income level, economic structure, and payment mechanisms for access to health services may explain the difference in CHE proportions.

The analysis of socioeconomic inequalities showed that the burden of $\mathrm{CHE}$ is concentrated in richer households, in contrast to results from Iran [36,37], Brazil [35] or China [38]. This can be explained by the segmentation in health insurance plans in Peru. In one extreme, the poorest people can receive free medication or simply forego healthcare due to incapacity to afford other expenditures. Thus, the lack of economic resources in these individuals prevents CHE. In the other extreme, the richest individuals can afford medicine or purchase private health insurance. However, due to the growing prevalence of diseases that demand long-term treatment and high technological resources, the budgets of even upper middle class individuals can be compromised, incurring CHE. In the middle of these extremes there is a proportion of individuals who are not considered or recognized as poor, and they, therefore, have difficulties applying for insurance. If this individual is a self-employed, non-dependent worker, then access to worker health insurance (Social Health Insurance) is not possible. In addition, if this individual has limited income, then it may not be able to purchase private health insurance [39]. Whatever the case, these individu- als may fall into the same situation as the poorest individuals.

Our results showed that $\mathrm{CHE}$ is dissimilar at a departmental level. CHE in poor households increased from 2008 to 2017 in departments such as Callao, Huanuco, Tacna and Tumbes. Some of these departments report a low supply of human resources and low availability of physical resources such as hospitals or health centres [40]. Inequalities of CHE and in the endowment of human and physical resources across the Peruvian departments reflect the inefficiency and ineffectiveness of the system to deliver health. Therefore, the public health system should implement mechanisms such as financial incentives for redistribution of human and physical resources to guarantee financial protection in each department.

This study has some limitations that must be taken into consideration in order to interpret the results. First, cross-sectional data are used instead of longitudinal data, and therefore, it is not possible to establish causality among the study variables. However, the data are representative at the national level and come from the only survey designed to measure the socioeconomic conditions of the Peruvian population. Second, the questions in the surveys related to the expenditure disbursed for health services may underestimate or overestimate the expenditure estimates because of the different question periods. Third, all expenditure questions were self-referred, and reported values may incur memory recall biases that could affect the accuracy of the information.

Although OOP and CHE decreased between 2008 and 2017, there is still socioeconomic inequality in relation to the burden of CHE across different subpopulations. To reverse this situation, it is necessary to effectively cover all the population, and promote, and guarantee access to health resources and services.

\section{SUPPLEMENTAL MATERIALS}

Supplemental material is available at https://doi.org/10. 3961/jpmph.20.035.

\section{CONFLICT OF INTEREST}

The authors have no conflicts of interest associated with the material presented in this paper.

\section{FUNDING}

None. 


\section{ACKNOWLEDGEMENTS}

The authors would like to thank the INEI that conducted the ENAHO and made the dataset and report available online.

\section{AUTHOR CONTRIBUTIONS}

Conceptualization: AHV, CRR. Data curation: AHV, CRR. Formal analysis: AHV, CRR. Funding acquisition: None. Methodology: AHV, CRR. Visualization: CRR. Writing - original draft: AHV, CRR, RVF, DR. Writing - review \& editing: AHV, CRR, RVF, DR.

\section{ORCID}

Akram Hernández- Vásquez https://orcid.org/0000-00031431-2526

Carlos Rojas-Roque https://orcid.org/0000-0002-1474-1550

Rodrigo Vargas-Fernández https://orcid.org/0000-00023310-8689

Diego Rosselli https://orcid.org/0000-0003-0960-9480

\section{REFERENCES}

1. World Health Organization. Sustainable health finance, universal coverage and social health insurance; 2005 [cited $2018 \mathrm{Jul}$ 2]. Available from: https://www.who.int/health_financing/ documents/cov-wharesolution5833/en/.

2. United Nations. Transforming our world: the 2030 agenda for Sustainable Development; 2015 [cited 2018 Jul 2]. Available from: https://www.un.org/ga/search/view_doc.asp?symbol= $\mathrm{A} / \mathrm{RES} / 70 / 1 \&$ Lang $=\mathrm{E}$.

3. World Health Organization. Out-of-pocket payments, user fees and catastrophic expenditure; 2018 [cited 2018 Jul 2]. Available from: http://www.who.int/health_financing/topics/financial-protection/out-of-pocket-payments/en/.

4. Oyarte M, Espinoza M, Balmaceda C, Villegas R, Cabieses B, Díaz J. Out-of-pocket expenditures in health and medications in Chile: comparative analysis between 1997, 2007, and 2012. Value Health Reg Issues 2018;17:202-209.

5. Deaton AS. The analysis of household surveys: a microeconometric approach to development policy (English); 1997 [cited 2018 Jul 2]. Available from: https://documents.worldbank. org/en/publication/documents-reports/documentdetail/ 593871468777303124/the-analysis-of-household-surveys-amicroeconometric-approach-to-development-policy.
6. Wagstaff A, Flores G, Hsu J, Smitz MF, Chepynoga K, Buisman $L R$, et al. Progress on catastrophic health spending in 133 countries: a retrospective observational study. Lancet Glob Health 2018;6(2):e169-e179.

7. World Health Organization. Health systems financing: the path to universal coverage: world health report 2010 [cited 2018 Jul 2]. Available from: https://www.who.int/whr/2010/en/.

8. Garg CC, Karan AK. Reducing out-of-pocket expenditures to reduce poverty: a disaggregated analysis at rural-urban and state level in India. Health Policy Plan 2009;24(2):116-128.

9. Organization for Economic Cooperation and Development (OECD). OECD reviews of health systems: Peru 2017; 2017 [cited 2018 Jul 2]. Available from: https://www.oecd-ilibrary.org/social-issuesmigration-health/oecd-reviews-of-health-systems-peru-2017/ access-and-quality-of-health-in-peru_978926428-2735-6-en.

10. Organization for Economic Cooperation and Development (OECD). Monitoring health system performance in Peru: data and statistics; 2017 [cited 2018 Jul 2]. Available from: https:// www.oecd.org/countries/peru/monitoring-health-systemperformance-in-peru-9789264282988-en.htm.

11. Instituto Nacional de Estadística e Informática. Social: living conditions and poverty; 2017 [cited 2019 Oct 1]. Available from: https://www.inei.gob.pe/estadisticas/indice-tematico/ sociales/ (Spanish).

12. Pan American Health Organization. Health in the Americas+, 2017 edition. Summary: regional outlook and country profiles; 2017 [cited 2019 Oct 1]. Available from: https://iris.paho. org/handle/10665.2/34321.

13. Ypanaqué-Luyo P, Martins M. Utilization of outpatient health services in the Peruvian population. Rev Peru Med Exp Salud Publica 2015;32(3):464-470 (Spanish).

14. Griffin JB, Osterbur EF. Cost, quality, and access of healthcare in Piura, Peru. Am J Undergrad Res 2019;16(2):17-30.

15. Hernández-Vásquez A, Vargas-Fernández R, Magallanes-Quevedo L, Bendezu-Quispe G. Out-of-pocket expenditure on medicines and supplies in Peru in 2007 and 2016. Medwave 2020;20(2):e7833 (Spanish).

16. Proaño Falconi $D$, Bernabé E. Determinants of catastrophic healthcare expenditure in Peru. Int J Health Econ Manag 2018; 18:425-436

17. Banco Central de Reserva de Perú. Consumer's Price Index (CPI); 2016 [cited 2018 Dec 23]. Available from: https://estadisticas. bcrp.gob.pe/estadisticas/series/anuales/resultados/PM05197PA/ html (Spanish).

18. Banco Central de la Reserva de Perú. American dollar (US\$); 
2017 [cited 2018 Dec 23]. Available from: https://estadisticas. bcrp.gob.pe/estadisticas/series/anuales/resultados/PM05309PA/html (Spanish).

19. Xu K, Evans DB, Carrin G, Aguilar-Rivera AM, Musgrove P, Evans T. Protecting households from catastrophic health spending. Health Aff (Millwood) 2007;26(4):972-983.

20. Xu K, Evans DB, Kawabata K, Zeramdini R, Klavus J, Murray CJ. Household catastrophic health expenditure: a multicountry analysis. Lancet 2003;362(9378):111-117.

21. Xu K, Klavus J, Kawabata K, Evans DB, Hanvoravongchai P, Ortiz de Iturbide J. Household health system contributions and capacity to pay: definitional, empirical and technical challenges. In: Murray CJ, Evans DB, editors. Health system performance assessment: debates, methods and empiricism. Geneva: World Health Organization; 2003, p. 533-563.

22. O'Donnell O, van Doorslaer E, Wagstaff A, Lidelow M. Analyzing health equity using household survey data: a guide to techniques and their implementation. Washington, DC: World Bank; 2008, p. 22.

23. van Doorslaer E, O'Donnell O, Rannan-Eliya RP, Somanathan A, Adhikari SR, Garg CC, et al. Catastrophic payments for health care in Asia. Health Econ 2007;16(11):1159-1184.

24. Organization for Economic Cooperation and Development (OECD). OECD framework for statistics on the distribution of household income, consumption and wealth; 2013 [cited 2018 Dec 23]. Available from: https://www.oecd.org/statistics/ framework-for-statistics-on-the-distribution-of-householdincome-consumption-and-wealth-9789264194830-en.htm.

25. Instituto Nacional de Estadística e Informática. Peru - National Household Survey on Living Conditions and Poverty 2017; 2018 [cited 2019 Jan 5]. Available from: http://webinei.inei. gob.pe/anda_inei/index.php/catalog/613 (Spanish).

26. Bradbury B, Jäntti M. Child poverty across the industrialised world: evidence from the Luxembourg Income Study. In: Vleminckx K, Smeeding TM, editors. Child well-being, child poverty and child policy: what do we know? 2nd ed. Bristol: Bristol University Press; 2001, p. 11-32.

27. Bradbury $B$, Jäntti $M$. Child poverty across twenty-five countries. In: Bradbury B, Jenkins SP, Micklewright J, editors. The dynamics of child poverty in industrialized countries. Cambridge: Cambridge University Press; 2001, p. 62-91.

28. Bradbury B, Jäntti M. Child poverty across industrialized nations; 1999 [cited 2019 Jan 5]. Available from: https://www. unicef-irc.org/publications/186-child-poverty-across-industrialized-nations.html.
29. O'Donnell O, O'Neill S, Van Ourti T, Walsh B. conindex: Estimation of concentration indices. Stata J 2016;16(1):112-138.

30. Wilson L, Velásquez A, Ponce C. Framework law on universal health assurance in Peru: analysis of benefits and systematic process from conception to its enactment. Rev Peru Med Exp Salud Publica 2009;26(2):207-217 (Spanish).

31. Bertranou F, Casanova L, Casalí P. The Peruvian health system: current situation and strategies to guide the extension of contributory coverage; 2013 [cited 2019 Jan 5]. Available from: https://www.ilo.org/americas/publicaciones/WCMS_213905/ lang--es/index.htm (Spanish).

32. Jacobs B, de Groot R, Fernandes Antunes A. Financial access to health care for older people in Cambodia: 10-year trends (2004-14) and determinants of catastrophic health expenses. Int J Equity Health 2016;15:94.

33. Yazdi-Feyzabadi V, Bahrampour M, Rashidian A, Haghdoost AA, Akbari Javar M, Mehrolhassani MH. Prevalence and intensity of catastrophic health care expenditures in Iran from 2008 to 2015: a study on Iranian household income and expenditure survey. Int J Equity Health 2018;17(1):44.

34. Pandey A, Kumar GA, Dandona R, Dandona L. Variations in catastrophic health expenditure across the states of India: 2004 to 2014. PLoS One 2018;13(10):e0205510.

35. Boing AC, Bertoldi AD, Barros AJD de, Posenato LG, Peres KG. Socioeconomic inequality in catastrophic health expenditure in Brazil. Rev SaudePublica 2014;48(4):632-641.

36. Rezaei S, Hajizadeh M, Ahmadi S, Sedghi S, Piroozi B, Mohamadi-Bolbanabad $A$, et al. Socioeconomic inequality in catastrophic healthcare expenditures in Western Iran. Int J Soc Econ 2019;46(9):1049-1060.

37. Rezaei S, Hajizadeh M. Measuring and decomposing socioeconomic inequality in catastrophic healthcare expenditures in Iran. J Prev Med Public Health 2019;52(4):214-223.

38. Xu Y, Gao J, Zhou Z, Xue Q, Yang J, Luo H, et al. Measurement and explanation of socioeconomic inequality in catastrophic health care expenditure: evidence from the rural areas of Shaanxi Province. BMC Health Serv Res 2015;15:256.

39. Francke P. Peru's comprehensive health insurance and new challenges for universal coverage (English) [cited 2019 Jan 5]. Available from: http://documents.worldbank.org/curated/ en/371851468086931725/Perus-comprehensive-health-insurance-and-new-challenges-for-universal-coverage.

40. Ministerio de Salud del Perú. Peruvian health situation; 2013 [cited 2019 Jan 5]. Available from: http://www.dge.gob.pe/ portal/docs/intsan/asis2012.pdf (Spanish). 